\title{
Preserving Colias myrmidone in European cultural landscapes: requirements for the successful development from egg to higher larval stages at a Natura 2000 site in Romania
}

\author{
Pauline Nippen ${ }^{1} \cdot$ Matthias Dolek ${ }^{2}$ Jacqueline $\operatorname{Loos}^{1}[$
}

Received: 22 February 2021 / Accepted: 4 June 2021 / Published online: 10 June 2021

(c) The Author(s) 2021

\begin{abstract}
The endangered and declining butterfly species Colias myrmidone is sensitive to land-use changes and vulnerable in its immature stages. The requirements for its larval habitats are still largely unknown, which hinders appropriate management in protected areas. We examined the relation between the larval development of $C$. myrmidone and environmental variables at a Natura 2000 site in Romania. Individuals that reached higher larval stages had a higher cover of litter as well as a lower cover of forbs around their host plants than individuals that died in early larval stages or as eggs. Surviving individuals had less other host plants in their surrounding and were found on larger host plants. Surviving individuals were found further away from the tip of their hosts than individuals that were lost due to grazing. The grazing regime is of particular importance to ensure the successful development of $C$. myrmidone from egg to higher larval stages. There seems to be a trade-off between positions at the tip of the shoot with palatable leaves and positions further down that protect against grazing. Especially sheep grazing may cause high direct mortality. The higher amount of litter around surviving larvae indicates a better survival when the grazing pressure is very low, but still present to keep the habitat open. However, occasional heavy grazing events may reduce the cover of forbs.

Implications for insect conservation The designation of the investigated Natura 2000 site offers a great opportunity to implement the insights on larval development of $C$. myrmidone into a management plan, which can support low-intensity grazing regimes preferably with cattle.
\end{abstract}

Keywords Area-based conservation $\cdot$ Danube Clouded Yellow $\cdot$ Larval ecology $\cdot$ Low-intensity farmland $\cdot$ Management

\section{Introduction}

The loss of biodiversity is one of the most severe challenges humanity is facing today. Extinction rates of vertebrates, and possibly also of invertebrates, lead to the hypothesis that the natural world is experiencing the sixth major extinction event in its history (Thomas et al. 2004). The conservation of biodiversity is crucial for the stability of many ecosystems and therefore important for safeguarding the resilience of the earth system (Steffen et al. 2015; Cardinale et al. 2012). One

Jacqueline Loos

jacqueline.loos@leuphana.de

1 Institute of Ecology, Leuphana University, Universitätsallee 1, 21335 Lüneburg, Germany

2 Büro Geyer \& Dolek, Alpenblick 12, 82237 Wörthsee, Germany of the main drivers of biodiversity loss are changes in landuse practices (Sala et al. 2000). In Europe and other parts of the world, humans have used land for centuries and created diverse cultural landscapes through a gradual co-evolution with nature that contained valuable habitats for a number of species (Horcea-Milcu et al. 2018; Settele et al. 2009a, b). In many of those semi-natural ecosystems, both the intensification of agricultural land-use as well as the abandonment of traditional management practices such as low-intensity grazing can cause species losses (Rosenthal et al. 2012; Roman et al. 2019).

Especially the diversity of insects has presumably decreased dramatically (Hallmann et al. 2017). Insects are connected to a variety of ecological functions and services such as pollination of crop and wild plants (Erhardt and Mevi-Schütz 2009; Biesmeijer et al. 2006). Nevertheless, only a small part of insect species is known so far (Thomas 2005) and despite numerous studies that agree with 
Hallmann et al. (2017) on the general decline of animal species (e.g. Seibold et al. 2019, van Klink et al. 2020), there are also results such as Crossley et al. (2020) for the US that do not reveal major changes. Therefore, it is necessary to extrapolate from subsets of well-known species groups to get an impression of actual changes in declines of insects and other invertebrates (Thomas 2005).

Butterflies are a well-studied group of insects and they may represent other invertebrate species (Thomas 2005). They are sensitive indicators of environmental changes. Moreover, the advantages of butterflies as indicator species lie in the simplicity of their identification, in their attractiveness and in the possibility to easily monitor and record them (Dennis 2009). Insects typically respond faster to adverse environmental changes than longer living organisms and the loss of butterflies may forecast similar declines in other species (Thomas et al. 2004). Declines in butterfly species can be understood as a warning signal and show the urgency for conservation measures to protect these valuable indicators and their habitats (Dennis 2009).

To design effective conservation strategies that halt or reverse declines of threatened butterfly species, detailed knowledge of their ecological requirements is needed (Ewing et al. 2020). Most butterflies have very specific preferences regarding habitat quality (Münsch et al. 2018; García-Barros and Fartmann 2009). Due to their complex life cycle from egg through different larval stages to pupae and finally to adults, requirements of butterflies have to be met in all of those stages (García-Barros and Fartmann 2009). The larval stage is expected to be particularly limiting (Ewing et al. 2020). Larval feeding is responsible for the accumulation of materials used for adult bodybuilding and egg production (Munguira et al. 2009). Most European butterfly species overwinter as larvae (Munguira et al. 2009) which stresses the importance of the larval stage for the survival of those species. Larvae depend on ephemeral and narrow niches within their habitats, which have to contain their larval host plants in specific growth forms and have to provide specific microhabitats (Ewing et al. 2020).

One of the most endangered butterfly species in Europe is the Danube Clouded Yellow (Colias myrmidone [ESPER, 1780]) (Dolek et al. 2005). C. myrmidone is listed in Annex II and IV of the EU Habitats Directive (2013/17/EU): its conservation requires the designation of special areas of conservation and the species needs strict protection. From its former distribution in eleven European countries, today C. myrmidone is only found in Poland, Romania and Slovakia (Marhoul and Dolek 2012). Its overall conservation status is either unfavourable bad or unfavourable inadequate (Marhoul and Dolek 2012, EEA and ETC/BD 2018). The reasons for the dramatic decline of $C$. myrmidone are unclear (Dolek et al. 2005). The butterfly seems to be threatened by factors on different scales: it is threatened by global climate change (Settele et al. 2008) and by large scale changes of local agriculture and forestry. C. myrmidone is presumably strongly affected by the transition from a small-scale mosaic-like management to intensive and uniform land-use practices (Marhoul and Dolek 2012). Its sensitivity to unfavourable changes in land-use is expected to be the main reason for its decline (Dolek et al. 2005). The intensification of management jeopardizes the development of the species as well as suitable host plants and nectar sources, but also abandonment of land and insufficient management are a threat to the species through the loss of its host plant by overgrowing (Marhoul and Dolek 2012). C. myrmidone counts as specialized species with specific requirements for microclimatic conditions and larval food plants (Freese et al. 2005). It is particularly vulnerable in its immature stages because larvae and eggs are not hidden (Freese et al. 2005). The female adults mostly lay their single eggs on the tips of fresh shoots of their larval host and food plant Chamaecytisus sp. (Dolek et al. 2005, Szentirmai et al. 2014) where the larvae then feed on (Konvicka et al. 2008). This leads to the management dilemma that on the one hand fresh shoots can only be provided if areas are managed with mowing or grazing, on the other hand such management can threaten the larvae through predation by livestock (Dolek et al. 2005).

Romania is one of the last strongholds of C. myrmidone (Loos et al. 2020). The species was probably widespread in large parts of the country but even there populations are decreasing dramatically (Marhoul and Dolek 2012, Iorgu et al. 2015). In Romania, an increasingly high grazing pressure is supposed to be the most important driver for the decline of $C$. myrmidone (Sielezniew et al. 2019). To ensure the survival of $C$. myrmidone and because of its obligations as a member state of the EU, Romania designated several Natura 2000 sites for the conservation of $C$. myrmidone (Loos et al. 2020). Knowledge on population ecology and habitat use of $C$. myrmidone, however, is still very limited (Szentirmai et al. 2014; Marhoul and Dolek 2012). Due to its vulnerability in the immature stages, knowledge of the specific requirements for the survival from egg to higher larval stages is needed to develop adequate management at those Natura 2000 sites.

The present study contributes to closing these research gaps and to gain a better understanding of the requirements of $C$. myrmidone in its critical egg and larval stages. Data were collected during field studies in summer 2019 in a newly established Natura 2000 site in Romania and analyzed to answer the following research questions:

- What is the survival rate of the eggs and larvae of $C$. myrmidone before hibernation? 
- Which environmental variables correlate with a high survival of eggs and larvae of C. myrmidone?

- Which role does grazing play for the survival of the eggs and larvae of $C$. myrmidone?

- Which measures should be taken in order to ensure a sufficient survival rate of eggs and larvae of C. myrmidone?

\section{Methods}

\section{Study species}

The distribution of C. myrmidone ranges from Central Europe across Eastern Europe to Western Asia. The former most western edge of its distribution range was Bavaria (Freese et al. 2005). All its habitats are characterized by a relatively continental climate (Dolek et al. 2005). C. myrmidone lives in calcareous grasslands, but prefers the vicinity to woodlands (Settele et al. 2009a, b). Besides natural grasslands, pastures and non-irrigated arable land, the butterfly also occurs in transitional woodland scrub (Loos et al. 2020). The species lives in traditionally managed cultural landscapes that contain a mosaic of meadows, pastures, orchards, open forests and woodland margins (Marhoul and Dolek 2012). It can cope with early successional stages, but further succession makes its habitats unsuitable (Loos et al. 2020). It is expected to have a low adaptive capacity, especially in terms of climate change (Sajwaj et al. 2011). The occurrence of $C$. myrmidone is restricted by the occurrence of its host plants of the genus Chamaecytisus sp. (Freese et al. 2005) which are adapted to light grazing and cannot develop if pastures are intensively grazed (Konvicka et al. 2008).

Usually, the butterfly is bivoltine. Adults of the first generation emerge in late May or early June, adults of the second generation emerge between mid-July and early September (Freese et al. 2005). In hot summers, a third generation may occur (Dolek et al. 2005). The larvae of the third instar hibernate in the litter on the ground or on the stems of their host plants (Freese et al. 2005). In this study, eggs and larvae laid by the second generation were observed. The observed individuals were expected to hibernate in the third larval stage and form the first generation of adults in the following year. Some of the eggs and larvae might have developed to adults in the same year and have formed a third generation as observed in previous years.

\section{Study area}

The study was conducted at a Natura 2000 site in Northwestern Romania close to the city Cluj-Napoca (Fig. 1). The site belongs to Cluj county and is located near the village Agârbiciu (ROSCI0274 Agârbiciu N 46²5'36.91";

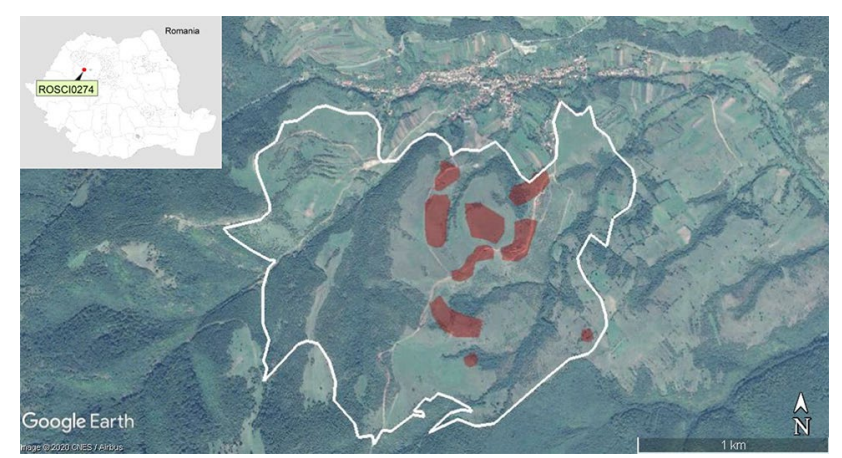

Fig. 1 Natura 2000 site ROSCI0274 in Romania and Agârbiciu (white line). The red patches indicate the nine areas that were searched for eggs and larvae. Shape of Romania obtained from Geofabrik GmbH/@ Open Street Maps, Satellite image (C) Google Earth (obtained via Google Earth Pro). Shape of Romania obtained from Geofabrik GmbH/@ Open Street Maps. (Color figure online)

$E 23^{\circ} 16^{\prime} 25.22^{\prime \prime}$ ) and covers a total area of $2.40 \mathrm{~km}^{2}$ (Loos et al. 2020).

Loos et al. (2020) analysed three newly established Natura 2000 sites designated for C. myrmidone in 2016 in Romania, including this study site. They found that the majority of parcels within these areas were used for grazing, and for haymaking. Also, most privately-owned land parcels at the Natura 2000 sites were smaller than 10 ha. Most of the grazed sites were classified as extensively managed, some were next to hay meadows or steep slopes that were not mown. Most farmers only mowed once a year, between the beginning of June till the beginning of September. Interventions carried out at the new Natura 2000 sites were the removal of weeds, ant hills, shrub and trees and sometimes stones. Some of the parcels were fertilized with manure (Loos et al. 2020). Grazing animals that were observed in the area were cattle, sheep and horses (Gallersdörfer and Newsom 2019). Loos et al. (2020) also recorded goats in 2016. Chamaecytisus triflorus was the only host plant of $C$. myrmidone present at the site.

\section{Data collection}

Data was collected during seven weeks from 31 July until 18 September 2019. First, nine areas on sun-exposed hillsides that were expected to meet the previously known requirements of the eggs and larvae of $C$. myrmidone were selected within the Natura 2000 site. The sizes of these areas ranged from 0.34 to -3.26 ha, with an average of 2 ha. These areas were then searched for the host plant Chamaecytisus triflorus. These host plants were then carefully assessed for eggs and larvae of $C$. myrmidone. To better understand the relationship between larval development and host plant conditions, we recorded the following host plant parameters: (1) coordinates, (2) number of other food plants around the 
respective food plant in a five-meter radius, (3) height and (4) width of the respective host plant, (5) height of caterpillar or egg above the ground and (6) distance of caterpillar or egg from the tip of host plants. (7) The ground cover in a radius of half a meter around occupied host plants was estimated, distinguishing cover of litter, grass, forbs and open soil. The branches on which recorded individuals were found, were marked with a tape to find them again. In the first two weeks of the study, food plants were searched for further eggs and larvae.

After the initial recording of eggs and larvae of C. myrmidone, all plants on which eggs and larvae had been found were checked again every two to three days to follow the development of individuals. Changes in the individuals were recorded including (1) the life stage of the individuals from egg to the fourth instar (abbr. L1, L2, L3, L4). The change from one to the next larval stage by molting was determined by head size in relation to body size and length. (2) The size of larvae as well as (3) new feeding traces on the plants were recorded. (4) Grazing animals as well as grazing signs on the host plants were recorded. On average, individuals were observed six times, with a minimum of one and a maximum of 19 observations.

\section{Statistical analysis}

Summary statistics were calculated for the individual egg or larvae sightings recorded at different stages and for environmental variables, to provide an overview of the data. Except for individuals that had already reached larval stage three or four, missing individuals were considered to be dead. For larvae in the third and fourth instar, it is possible that they were not found again because they moved too far from their former position on the plant. For those missing individuals, mortality cannot be distinguished from mobility. Therefore, all individuals that had reached at least the third instar were considered to have successfully developed.

To calculate survival rates of each larval stage, individuals were divided into groups dependent on the highest larval stage they had reached (maximum: larval stage three). Individuals with unknown latest stage, i.e. those that went missing but had not been recorded as such for at least three occasions, were excluded from the analysis. Only individuals that were initially recorded as eggs were included in the calculation of survival rates. Survival rates between the stages were calculated as well as the survival rate from egg to all larval stages. The calculated survival rates are the minimum survival rates because a slight uncertainty remains regarding the death of missing individuals. To estimate the maximum survival rate, for all missing individuals feeding traces were analysed. Missing individuals on branches with new feeding traces were assumed to have reached the next larval stage.
The individuals that survived to different larval stages were grouped and tested for significant differences in the expression of environmental variables, running an ANOVA. To investigate significant differences between the groups, a Tukey's HSD test was performed. The analysis was carried out on the following environmental variables: (1) the height and (2) width of plants, (3) the height of individuals above the ground and (4) their distance from the tip of their food plants, (5) the number of other food plants around the respective host plant and (6) the variables of the ground cover: litter, grasses, forbs and open soil. Environmental variables were visually checked for normal distribution. In accordance to Blanca et al. (2017), who found that the F-Test is robust to departures from normality, even with various sample sizes, we decided to keep the data of plant characteristics and of the position of individuals on plants untransformed. The data of the ground cover which was recorded in percentages was arcsin transformed as recommended by Fernandez (1992).

For further analysis, for each larval stage as well as the egg stage, individuals were separated in the ones that died in or before a specific stage or survived that stage and reached the next larval stage. For each stage, these two groups were then tested for differences in environmental variables using a t-test. Individuals of unknown fate were excluded from the analysis.

To analyse whether differences in environmental variables correlated with different death reasons or survival, individuals of the whole dataset were grouped according to their observed last state, specifically their reason of death or survival. These reasons were categorized as follows: survived; dead; missing; predated; grazed; whereby the category 'dead' stated the death of an individual without reference to any obvious reason, 'missing' described that previously detected eggs or larvae were not found again for at least three times, 'predated' applied when individuals, mainly eggs, had been destroyed by parasitoids, and the category 'grazed' described that either an egg or a larvae had obviously been destroyed by grazing, e.g. when a plant had been grazed or trampled by livestock. In this analysis, surviving individuals are only the ones that were actually found alive at the end of the study, regardless of their larval stage. These groups were tested for differences in the expression of environmental variables, running an ANOVA supplemented by a Tukey's HSD test.

All statistical analyses were carried out with RStudio version 1.2.5033 under $\mathrm{R}$ version 3.6.2.

\section{Results}

In total, 314 individuals were recorded at the selected areas in Agârbiciu that could be used for the analysis. Of those, 273 individuals were first recorded as eggs, 41 individuals 
Table 1 Number of individuals in the different stages in their respective first (first observed observed stage). $\mathrm{N}=314$ stage) and last observation (last

\begin{tabular}{lrl}
\hline Stage & $\begin{array}{l}\text { First } \\
\text { observed } \\
\text { stage }\end{array}$ & $\begin{array}{l}\text { Last } \\
\text { observed } \\
\text { stage }\end{array}$ \\
\hline Egg & 273 & 148 \\
L1 & 8 & 57 \\
L2 & 8 & 42 \\
L3 & 24 & 56 \\
L4 & 1 & 11 \\
\hline
\end{tabular}

Table 2 Number of individuals with different death reasons or survival. Missing individuals were not found again for at least three times, individuals with an unknown last state were not observed until the end of the study. $\mathrm{N}=314$

\begin{tabular}{lr}
\hline Last state & Total data set \\
\hline Found dead & $40(12.7 \%)$ \\
Grazed & $22(7.0 \%)$ \\
Missing & $193(61.5 \%)$ \\
Predated & $27(8.6 \%)$ \\
Survived & $12(3.8 \%)$ \\
Unknown & $20(6.4 \%)$ \\
\hline
\end{tabular}

were first recorded as larvae. The highest observed larval stage was the fourth stage (Table 1).

Most individuals (61.5\%) went missing, meaning that they could not be found again for at least three times and were expected to be dead (Table 2). Including all individuals that were actually found dead, that were grazed or predated, $89.8 \%$ (282) very likely died. The remaining individuals survived (3.8\%) or their last state is unknown (6.4\%).

The host plants of the recorded individuals had an average height of $40 \mathrm{~cm}$ and were on average $48 \mathrm{~cm}$ wide (Table 3 ). The individuals were on average positioned $9 \mathrm{~cm}$ below the tip of the food plant with a median at $8 \mathrm{~cm}$. In a fivemeter radius around the occupied host plants, on average twelve other host plants were found, with a minimum of one other host plant and a maximum of 43 other host plants. The ground cover in half-a-meter radius around occupied host plants was composed as follows: On average, $8 \%$ of the ground was covered by open soil, $4 \%$ was covered by litter, $50 \%$ was covered by grass and $36 \%$ was covered by forbs. The cover of litter and the cover of open soil was not normally distributed: the majority of occupied host plants had almost no cover of open soil or litter, whereas a minority had a high cover of open soil or litter (Table 4).
Table 4 Cover of the ground in a $0.5 \mathrm{~m}$ radius around the host plants

\begin{tabular}{lllll}
\hline Sample size & Cover type & Median $(\%)$ & Mean $(\%)$ & SD (\%) \\
\hline 314 & Grass & 50.0 & 50.2 & 16.11 \\
314 & Herbs & 40.0 & 36.37 & 15.7 \\
310 & Litter & 0.0 & 3.7 & 10.93 \\
314 & Open soil & 0.0 & 7.57 & 12.64 \\
\hline
\end{tabular}

\section{Survival rates}

From the 264 individuals that were found as eggs in the beginning of the study, $13 \%$ survived until the third instar (Fig. 2). An uncertainty regarding the missing individuals remains. Between all stages, the minimum survival rate is around $50 \%$. From each stage, around $50 \%$ of the individuals reached the next stage, the other half most likely died. The maximum survival rate is assuming that missing individuals survived. It is only slightly higher for the survival from egg to the first instar, while the survival from the first to the second larval stage and from the second to the third larval stage might have been much higher. Of the 35 individuals that reached larval stage three, five larvae were later found in the fourth instar, five other individuals were recorded dead and 21 individuals went missing. Four of those individuals were found alive at the end of the study.

\section{Environmental variables}

Figure 3 shows the results of the t-test for selected characteristics of the host plants. Individuals that reached the third larval stage were on average located higher than those of individuals that most likely died before reaching the third instar (t-test: $t(104.24)=-1.85, p=0.067)$. The height of individuals above the ground correlated with the height of the respective host plants (correlation $=0.62$ ) and was higher in individuals that reached larval stage three compared to those that died in younger instars (t-test: $\mathrm{t}(87.44)=-3.1$, $\mathrm{p}<0.01)$. Individuals that died before reaching the second instar were positioned closer to the tip than the ones that reached the second larval stage (t-test: $\mathrm{t}(208.13)=-2.25$, $\mathrm{p}=0.025)$. This trend was also found between all individuals that died before developing to the third instar and the ones that reached larval stage three (t-test: $\mathrm{t}(86.12)=-1.8$,
Table 3 Plant characteristics of occupied host plants and position of eggs and larvae on plants

\begin{tabular}{llcc}
\hline Sample size & Variable & Mean & SD \\
\hline 314 & Height of food plant $(\mathrm{cm})$ & 39.87 & 14.7 \\
310 & Width of food plant $(\mathrm{cm})$ & 48.46 & 23.14 \\
307 & Height of egg or larvae above ground $(\mathrm{cm})$ & 28.79 & 10.75 \\
304 & Distance of egg or larvae from tip of the plant $(\mathrm{cm})$ & 9.29 & 8.5 \\
295 & Number of food plants in the surrounding & 11.98 & 8.15 \\
\hline
\end{tabular}




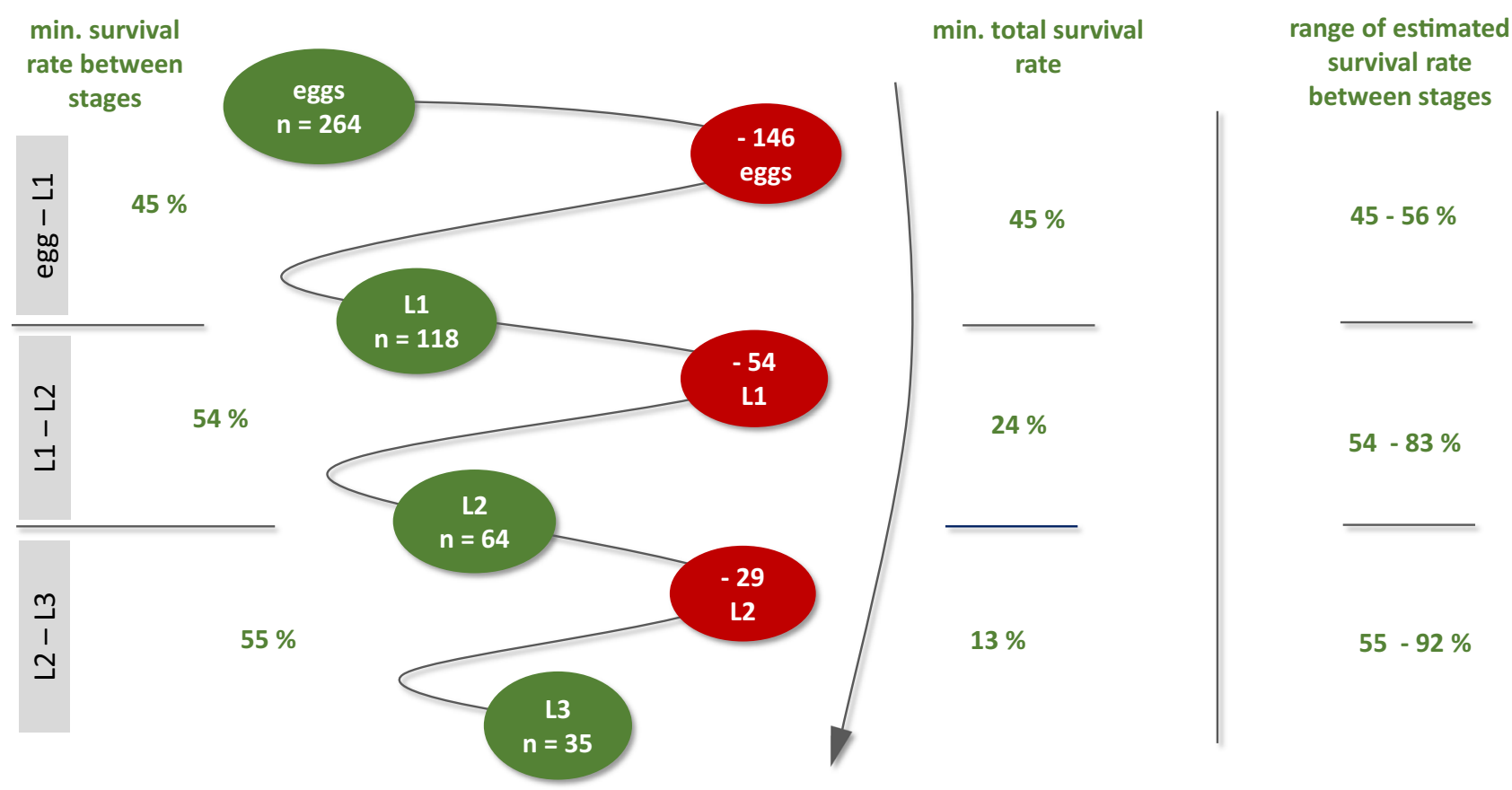

Fig. 2 Survival rates until the third instar. Only individuals that were first recorded as eggs are included. $N=264$

$\mathrm{p}<0.1)$. The number of food plants around the occupied host plants was lower in individuals that reached third instar than for those that died before ( $t$-test: $\mathrm{t}(120.41)=3.344$, $\mathrm{p}<0.001)$.

Ground cover differed significantly between groups of individuals reaching different highest instars (Fig. 4). The cover of litter differed significantly among the groups (ANOVA: $F(3,295)=17.79, \mathrm{p}<0.0001)$ and was highest in the group that reached the third larval stage (Tukey's HSD test: egg - L3 $\mathrm{p}_{a d j}=0.0, \mathrm{~L} 1-\mathrm{L} 3 \mathrm{p}_{a d j}=0.0, \mathrm{~L} 2-\mathrm{L} 3 \mathrm{p}_{a d j}$ $<0.0001)$. Also, the cover of forbs differed among groups $($ ANOVA: $F(3,299)=8.252 \mathrm{p}<0.0001)$. The cover of forbs was lower in the larvae that reached the third instar compared to individuals that already died as eggs (Tukey's HSD test: $\left.\mathrm{p}_{a d j}<0.0001\right)$ or died in the first larval stage (Tukey's HSD test: $\mathrm{p}_{a d j}<0.001$ ), but was not significantly lower compared to individuals dying in the second instar (Tukey's HSD test: $\mathrm{p}_{a d j}=0.105$ ). There was neither a significant difference found between groups in the cover of open soil (ANOVA: $F(3,299)=0.088, p>0.9)$ nor in the cover of grass (ANOVA: $\mathrm{F}(3,299)=0.176, \mathrm{p}>0.9)$.

Following variables differed significantly among the groups of individuals with different last states: the height of the plants (ANOVA: $\mathrm{F}(4,289)=5.413$, $\mathrm{p}<0.001$ ), the distance from tip (ANOVA: F 4 , 280) $=6.155$, p < 0.0001) and the height of eggs or larvae above the ground (ANOVA: F(4, $283)=4.07$, p < 0.01, Fig. 5). For the width of plants, there was a trend for differences among groups (ANOVA: F(4, $285)=2.196, p=0.0695)$. The height of plants was lower in individuals that were lost due to grazing, compared to all other groups (Tukey's HSD test: grazed-survived $\mathrm{p}_{a d j}$ $<0.001$, grazed—missing $\mathrm{p}_{a d j}<0.01$, grazed — dead $\mathrm{p}_{a d j}<$ 0.01 , predated-grazed $\left.\mathrm{p}_{a d j}<0.05\right)$. The same was found for the height of eggs or larvae above the ground, except for individuals that were actually found dead (Tukey's HSD test: grazed-survived $\mathrm{p}_{a d j}<0.01$, grazed-missing $\mathrm{p}_{a d j}<$ 0.05 , grazed-dead $\mathrm{p}_{a d j}=0.065$, predated-grazed $\mathrm{p}_{a d j}<$ 0.01). The width of host plants of individuals lost through grazing was lower compared to the width of host plants of missing individuals (Tukey's HSD test: $\mathrm{p}_{a d j}=0.048$ ), but showed no significant difference compared to the individuals that survived. Individuals that were lost due to grazing were positioned closer to the tip than the individuals that were found dead (Tukey's HSD test: $\mathrm{p}_{a d j}<0.01$ ), or that were missing (Tukey's HSD test: $\left.\mathrm{p}_{a d j}<0.05\right)$ and that survived (Tukey's HSD test: $\mathrm{p}_{a d j}<0.001$ ). Predated individuals were also positioned closer to the tip of their host plants than surviving individuals (Tukey's HSD test: $\mathrm{p}_{a d j}<0.01$ ). No significant differences in the number of food plants around the respective host plants could be found between the different groups (ANOVA: $\mathrm{F}(4,270)=2.299$, $\mathrm{p}=0.059$ ).

One of the nine observed areas had to be completely abandoned after a flock of sheep grazed on it. Occupied food plants were almost completely destroyed and no eggs or larvae were found anymore. Such damages were not observed from cattle that autonomously moved through the study site in groups of five to ten animals (Gallersdörfer and Newsom 2019). 


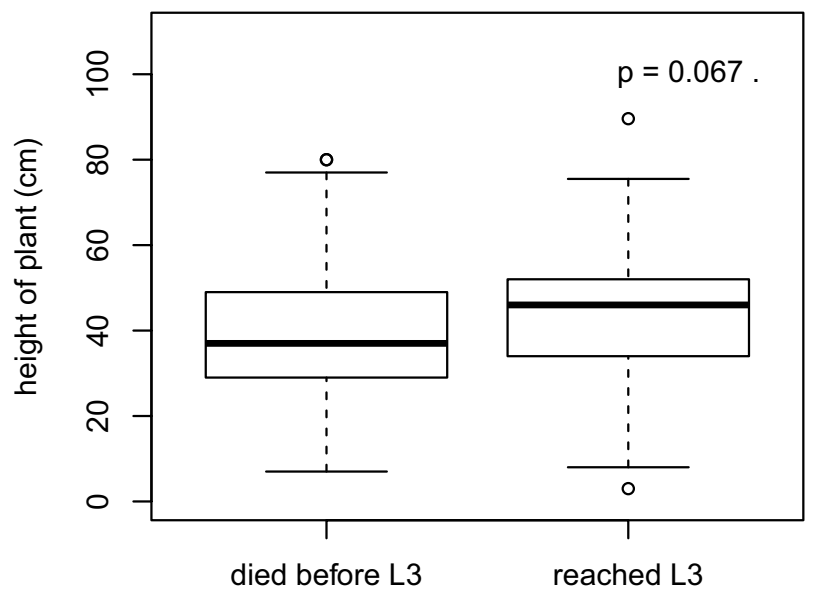

larval stage

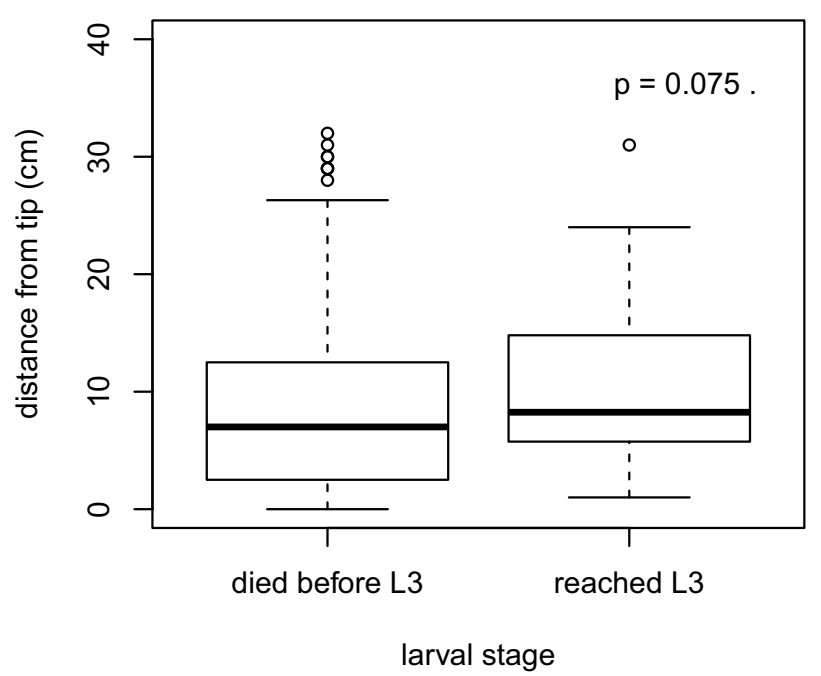

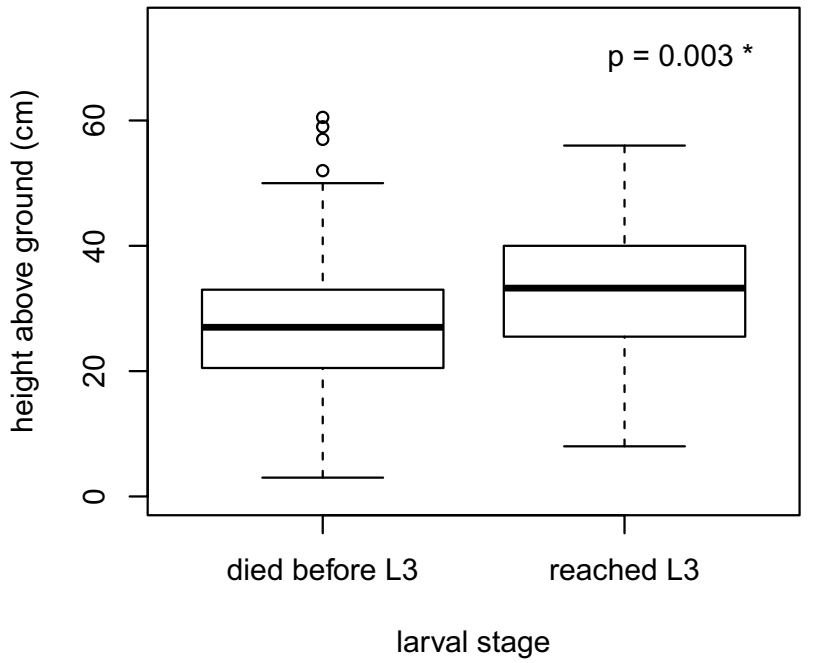

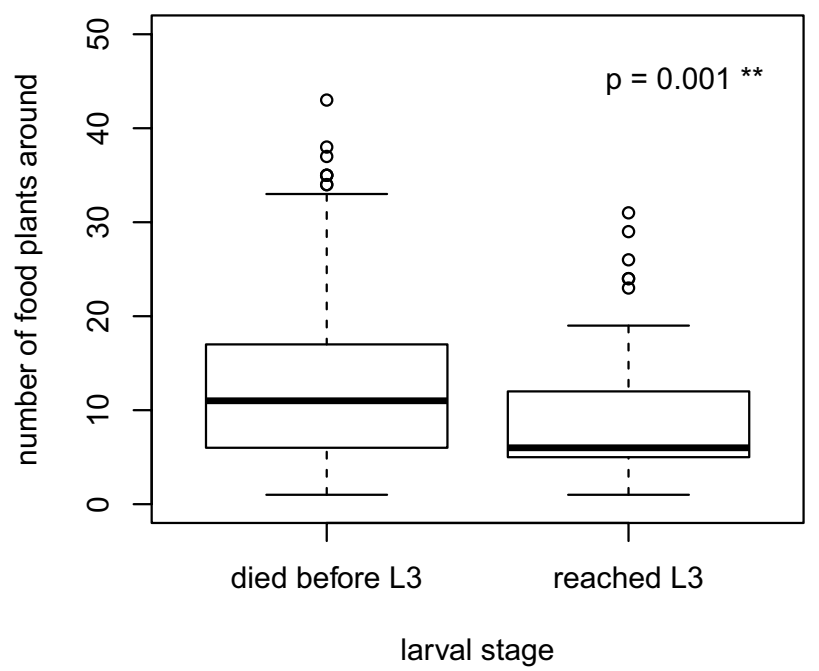

Fig. 3 Differences in characteristics of host plants and position of individuals on plants, comparing individuals that died before reaching the third instar or reached at least larval stage three. P-value of Welch Two Sample t-test $(\mathrm{N}=314)$

\section{Discussion}

This study provides a comprehensive analysis of environmental variables that might influence the development from egg to higher larval stages of $C$. myrmidone was done. Of the individuals that were found as eggs in the beginning of the study, $13 \%$ reached at least larval stage three. The analysis revealed, that reaching higher larval stages was correlated with a high cover of litter in the surrounding of the host plants. The opposite was found for the cover of forbs: individuals that reached higher larval stages were found on host plants surrounded by a comparatively lower herb cover. Individuals that developed at least until the third instar were found on higher food plants, were positioned further away from the tip of plants and higher above the ground than the individuals that were lost before reaching the third larval stage. Larvae that reached the third instar were found on host plants with significantly less other host plants in the immediate surrounding. The results indicate correlations of environmental variables to grazing, showing that the individuals that were lost due to grazing were positioned comparably close to the tip of their host plants and were found on smaller host plants.

\section{Survival rates}

The high range between the minimum and the maximum estimated survival rates, especially between higher larval stages, indicates that the survival of larvae might have been higher than $13 \%$. However, it remains unclear whether the feeding traces stemmed from the specific individuals or from other caterpillars or herbivores. Furthermore, it cannot be 


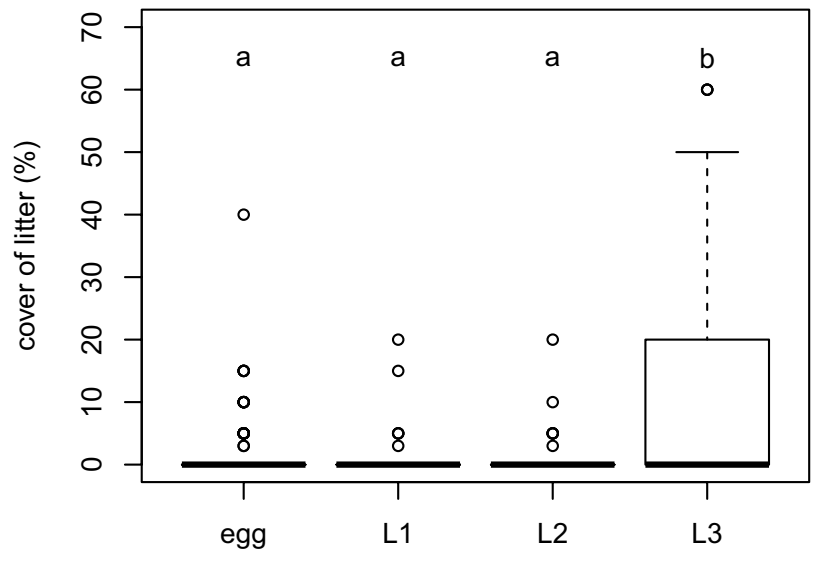

highest larval stage reached

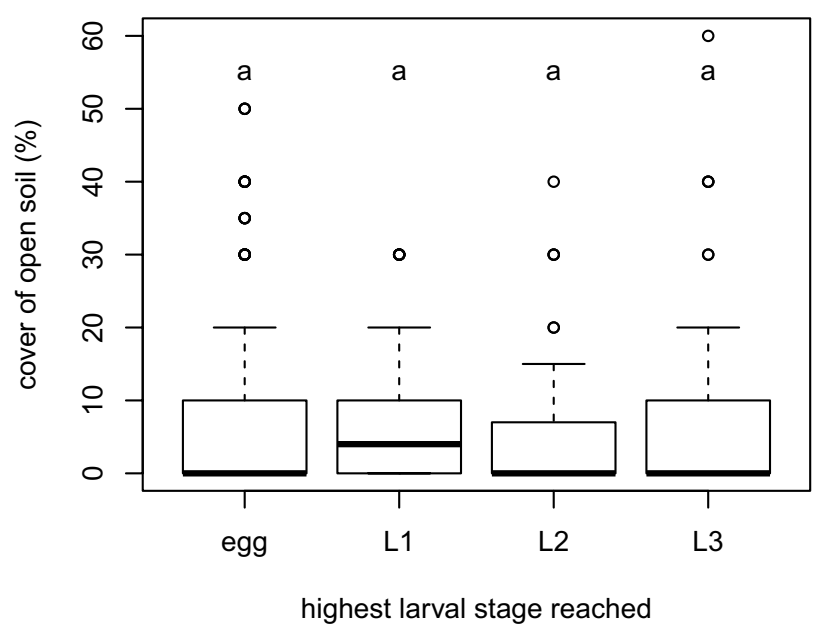

Fig. 4 Differences in the ground cover in a half meter radius around the occupied host plants of individuals that died in different larval stages or as eggs or reached larval stage three. Different letters indi-

predicted whether those individuals actually reached the next larval stage and how far they developed. Dolek et al. (2019) conducted a similar study on Colias palaeno where the mortality of young larvae before hibernation was a crucial factor for the survival of the species. They found a survival rate of $18.3 \%$ before hibernation in suitable habitats, which is supposed to be sufficient for the survival of Colias palaeno (Dolek et al. 2019). Also other studies found higher survival rates than we did: Hayes (1981) detected $21.7 \%$ survival from egg to young instar three and $9.9 \%$ to diapausing instar three for Colias alexandra. Freese et al. (2006) report a 30\% survival rate for Euphydryas maturna from egg to hibernation. As some uncertainty remains about the actual fate of missing individuals and thus about the exact survival rate of $C$. myrmidone in our study, the minimum survival rate (considering missing individuals as dead) seems more reliable than the maximum calculated survival rate (considering missing individuals as surviving). It cannot be ruled
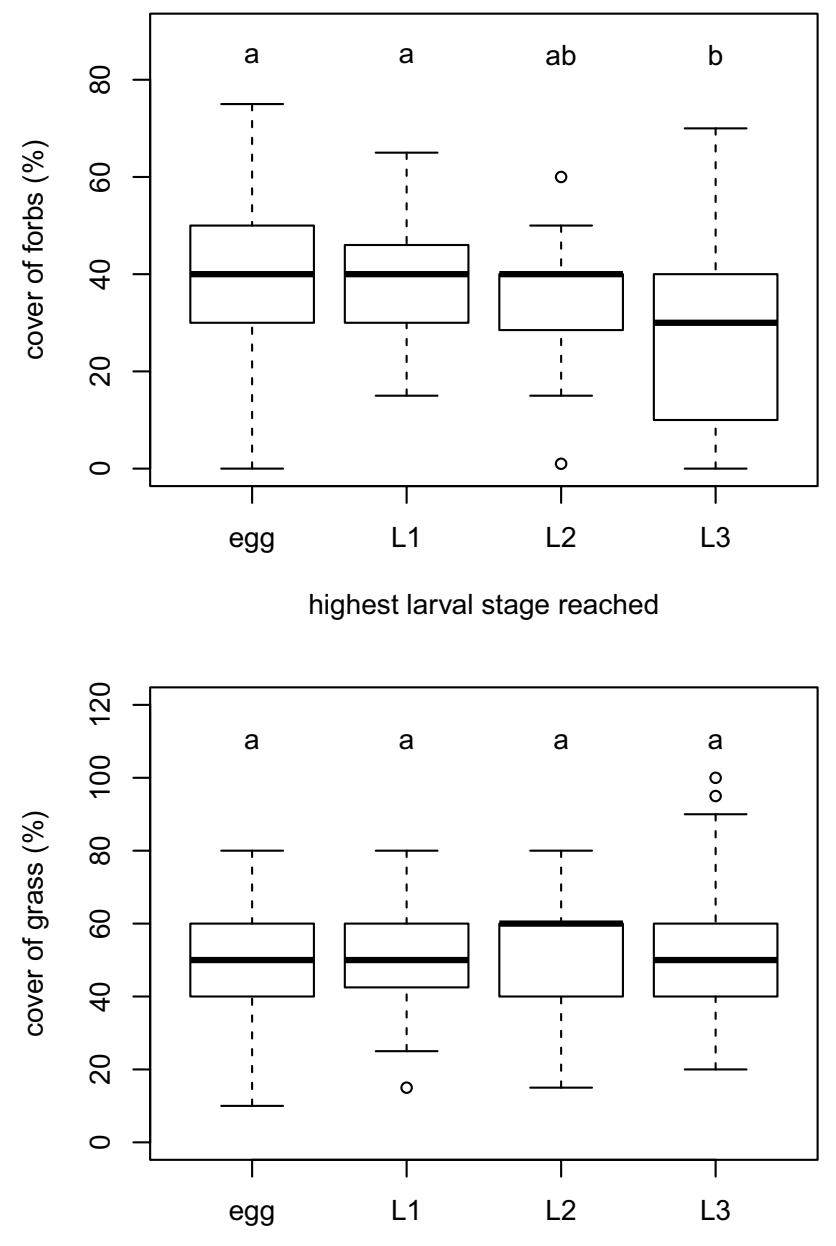

highest larval stage reached

cate significant differences between the groups, calculated by Tukey's HSD test after the data was arcsin transformed. Level of significance: $\mathrm{p}<0.05(\mathrm{~N}=303)$

out that the survival rate of $C$. myrmidone at the Natura 2000 site in Agârbiciu might actually be comparably low, especially considering that larvae were not observed until hibernation. The survival rate until hibernation therefore is probably even lower. These findings emphasize the need for adequate protection measures to keep the survival rate at least on the current level.

\section{Environmental variables}

Individuals that reached higher larval stages were found on host plants surrounded by a higher cover of litter. Other studies found similar results and draw a connection to the grazing regime at the sites. For the butterfly species Erebia epiphron, the Mountain Ringlet, Ewing et al. (2020) found that the quantity of leaf litter influenced egg site selection. Females preferred sites with an intermediate amount of litter. The cover of litter is supposed to function as a microclimatic 


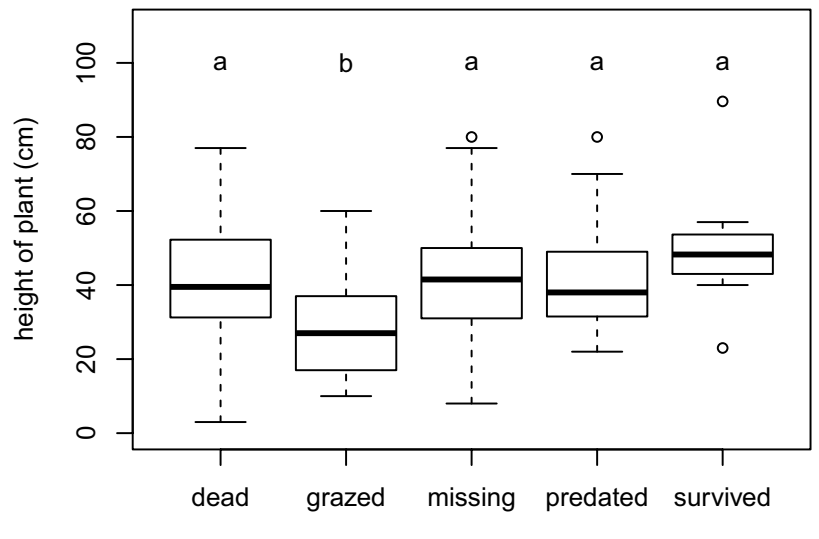

last state

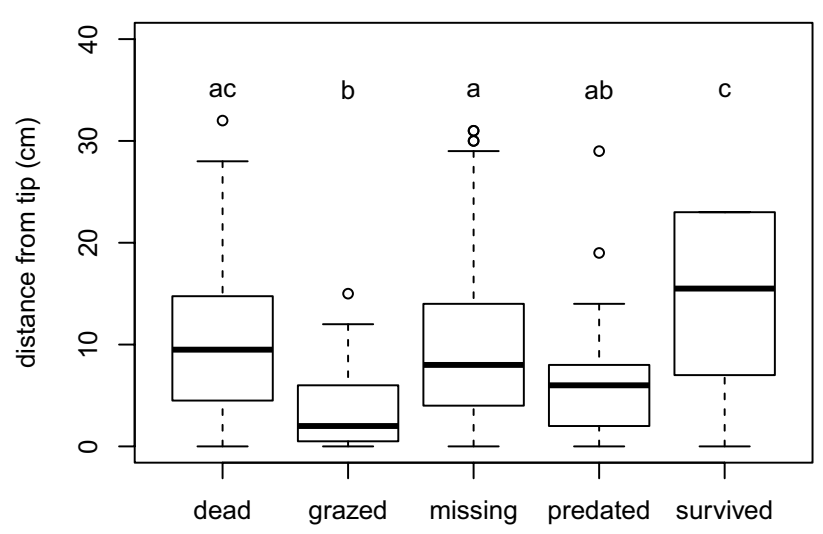

last state
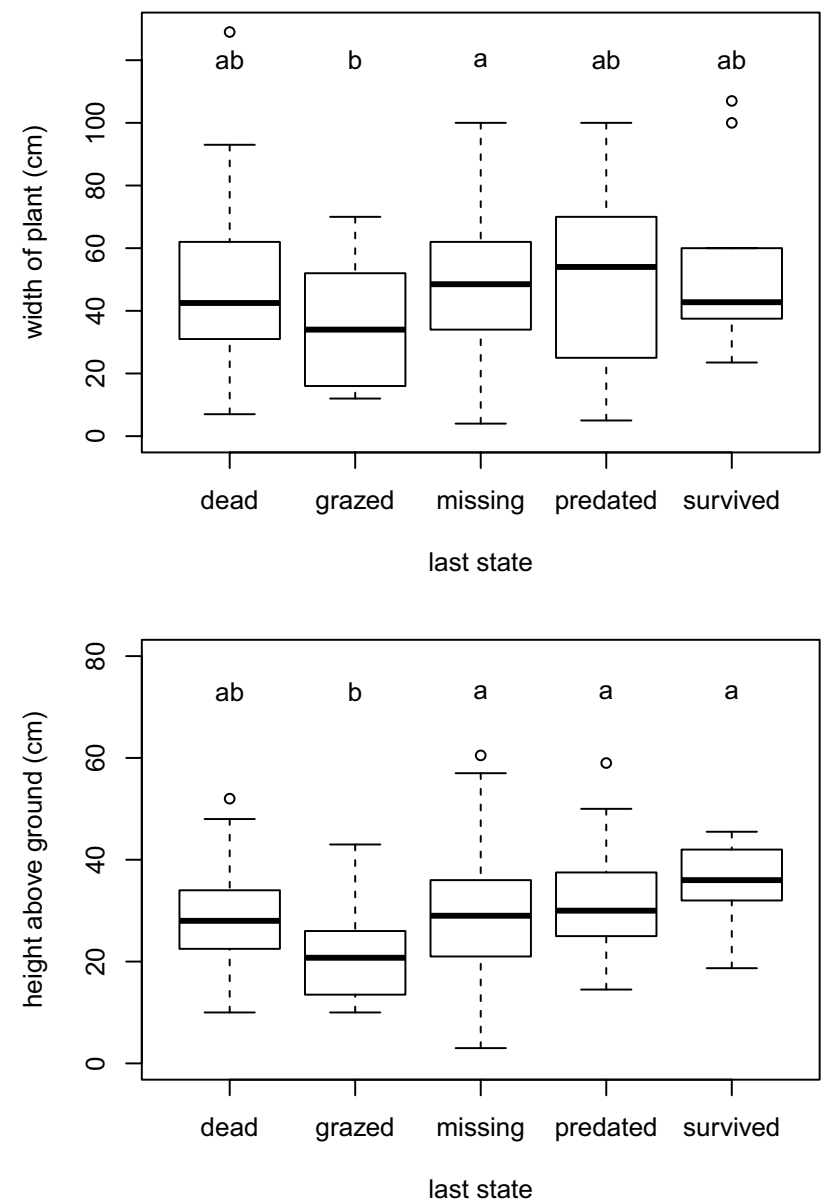

Fig. 5 Differences in environmental variables of individuals with different last states. Different letters indicate significant differences between the groups calculated by Tukey's HSD test. Level of significance: $\mathrm{p}<0.05(\mathrm{~N}=294)$

buffer that reduces temperature and humidity fluctuations and protects hibernating larvae from cold temperatures in winter (Stuhldreher and Fartmann 2014; Münsch et al. 2018; Ewing et al. 2020). Cold temperatures probably had no influence on the survival of the larvae of $C$. myrmidone in September, still it might be advantageous for their hibernation. In addition, Ewing et al. (2020) expect that intensive sheep grazing regimes may lead to a less well-developed litter layer. The same is expected by Münsch et al. (2018) who found that the occurrence of two specialist butterfly species in semi-natural grasslands in Central Germany was determined by the litter volume. For Coenonympha oedippus, Čelik et al. (2015) observed that the amount of litter is an important determinant of habitat quality via its influence on microstructure and microclimate. Large amounts of litter are an indicator of decreasing land-use intensity (Münsch et al. 2018). Abandonment of habitats maintains the litter layer in short term, but is expected to be disadvantageous in the long term because it leads to a vegetation composition dominated by competitive, high-growing grasses (Stuhldreher and Fartmann, 2014; Münsch et al. 2018).
Females of the Mountain Ringlet selected sites for egglaying that had shorter and sparser vegetation which may minimize the potential shading effects of taller vegetation (Ewing et al. 2020). It can be hypothesized that a high herb cover around food plants of $C$. myrmidone is disadvantageous because it overgrows food plants and creates shade that inhibits the neccessary warm microclimate on the plants (Dolek et al. 2005). However, during observations no data on the height of surrounding forbs was collected. In addition, the cover of grasses that might also overgrow host plants did not show any significant differences between groups.

The analysis showed that individuals that survived until at least the third larval stage were positioned on higher host plants than the ones that died before reaching the third instar. According to García-Barros and Fartmann (2009), the size of host plants is often correlated with the amount of food available for the larvae. Furthermore, large host plants provide a high passive protection for the eggs and larvae and can function as a buffer against larval competition. Therefore, usually large plants are preferred over small ones during oviposition (García-Barros and 
Fartmann 2009). The fact that surviving individuals of $C$. myrmidone were positioned on higher food plants suggests that the passive protection of those high hosts might have been advantageous for their survival.

Surviving individuals were positioned higher above the ground. This is in line with the former observation that larvae feed preferably at the tips of fresh shoots of their host plants and benefit from a warm microclimate (Dolek et al. 2005; Konvicka et al. 2008). Additionally, fresh leaves usually have higher amounts of water and nitrogen than old ones (Munguira et al. 2009). It can therefore be assumed that the proximity to the tip of plants is advantageous for the survival of the eggs and larvae of $C$. myrmidone. In contrast to that, the results showed that individuals that survived until the third larval stage were positioned further away from the tip of plants than the ones that died before. Especially the individuals that were lost due to grazing or predation were positioned closer to the tip of plants. This, in turn, proposes that individuals that are positioned further away from the tip of plants are better protected from grazing animals and parasitoids. These results can lead to the assumption that a trade-off exists between a good microclimate and nutrient supply at the tip of fresh shoots and a better protection further away from the tip of host plants.

Individuals that died before reaching larval stage three had more other host plants around their respective host plant. This result contradicts findings of female butterflies of other species that laid their eggs at sites where food plant abundance is high (Ewing et al. 2020), probably to ensure sufficient availability of food for larvae that are less mobile (Curtis et al. 2015). In contrast, a study of oviposition site selection of Phengaris alcon found that females laid eggs on less aggregated host plants (Vilbas et al. 2016). C. myrmidone is a mobile butterfly in the adult stage, but in captivity it was observed that caterpillars do not move far from the tip of their respective host plant, even though they get more mobile in higher larval stages (Dolek et al. 2005). A low mobility of larvae would lead to the assumption that a high density of host plants on patches would be beneficial for the species. However, a single food plant of Chamaecytisus is usually large enough to support the development of a caterpillar of $C$. myrmidone. Further research is needed to understand the reasons for the correlation of lower food plant density and the survival until higher larval stages. It may indicate less suitable conditions as it was observed for $C$. palaeno (Dolek et al. 2019).

\section{The role of grazing}

Comparing the different death reasons of individuals revealed information on the individuals that were lost due to grazing. Individuals that were lost due to grazing were positioned close to the tip of plants and had smaller host plants. In correlation to that, they were also positioned comparatively closer to the ground. The results further confirm the former described dilemma that sites have to be managed with mowing or grazing to provide fresh shoots for the larvae, but at the same time grazing and mowing threatens the larvae (Dolek et al. 2005; Szentirmai et al. 2014; Konvicka et al. 2008). The results indicate that the individuals being close to the tips are especially vulnerable to grazing. The fact that individuals that were directly lost through grazing had comparatively smaller host plants can either be explained by the grazing behaviour of grazing animals that might prefer smaller plants, or, more likely, those plants were positioned at sites where they were exposed to grazing animals more often also in the past.

Previous studies stressed the importance of grazing for declines in populations of C. myrmidone (Loos et al. 2020; Konvicka et al. 2008). In this study, the loss of only 22 of 314 individuals could be directly assigned to grazing animals. Even though the number of individuals directly lost through grazing was low (7\%), the observed flock of sheep that destroyed the majority of larvae in one of the observed areas shows the sensitivity of $C$. myrmidone to grazing events. Also, the comparatively low cover of litter around individuals that died before reaching larval stage three showed that indirectly, the effects of grazing might have a negative impact on the survival of eggs and larvae.

\section{Implications for conservation}

In a study conducted in 2017, adults of $C$. myrmidone were recorded in three newly established Natura 2000 sites, of which one is the site of this study in Agârbiciu. Even though the site in Agârbiciu is the smallest of the three Natura 2000 sites, the highest number of individuals could be found in that site (Vizauer et al. 2018). The observed survival of the larvae before hibernation is probably sufficient for the survival of the population, but the results still confirm the vulnerability of $C$. myrmidone to grazing events and unsuitable habitat characteristics. Therefore, further adaption of management is needed to ensure the survival of $C$. myrmidone in Agârbiciu. Management recommendations can be derived for its protection and reintroduction in other European cultural landscapes where it used to occur.

Based on the results of this study, the following conditions are considered beneficial for the successful development of the immature stages of $C$. myrmidone and should be implemented in the further management of occupied or potential habitats: a high cover of litter, a comparably lower cover of forbs around host plants and large host plants, a reduction of the probability for adverse effects on individuals 
that are positioned close to the tips of fresh shoots and a more scattered distribution of host plants among the sites.

A major factor to meet those requirements are adaptions to the grazing regime. Loos et al. (2020) found that many farmers at the three newly established Natura 2000 sites in Romania received subsidies for grazing. Konvicka et al. (2008) state that the minimum daily stocking prescribed for provisions for grazing through Agri-EnvironmentalSchemes are too high compared to light grazing. Therefore, other incentives should be created that motivate farmers in the Natura 2000 site to keep their low-intensity management and that allow to adapt management to the diverse requirements of the butterfly (Settele et al. 2009a, b).

There might be differences in the type of grazing animals that suit the requirements of $C$. myrmidone. Grazing of sheep and goats is characterized by a precise selection for palatable plants and they prefer forbs and legumes. Cattle and horses select fodder based on the characteristics of larger spatial units and less on individual plants, they mainly select for grasses (Rosenthal et al. 2012). Grazing of sheep and goats can be disadvantageous for the eggs and larvae of C. myrmidone because the host plant Chamaecytisus triflorus is a legume and described as a palatable plant for livestock and particularly liked by goats (M'Rabet et al. 2017). In contrast to that, cows and horses may be more likely to avoid Chamaecytisus triflorus or only feed on it by chance. Especially the number of sheep and goats at the site has to be reduced to a number which enables grazers to regularly reach all potentially palatable plants (Rosenthal et al. 2012).

The results of this research suggest that grazing of sheep and goats during egg and young larval stages of C. myrmidone should be avoided. This finding challenges the wide replacement of cows by sheep since Romania's accession to the EU in 2007, which has been sparked by per-unit subsidies for livestock despite the degrading effects on vegetation (Mikulcak et al. 2013). Moreover, grazing of cows and horses should be reduced during that time to ensure a stable litter cover and host plants with sufficient height and to protect eggs and larvae on the tips of their host plants. However, frequent but low-intensity grazing by sheep and goat prevent succession and reduce the cover of forbs that may overgrow Chamaecytisus triflorus and lead to suboptimal microclimatic conditions for the eggs and larvae of $C$. myrmidone.

\section{Open questions and outlook}

Indicators of requirements for the successful development from egg to higher larval stages of C. myrmidone were found in this study that supplement or confirm former findings. Especially grazing is supposed to play an important role for the survival of the species in its early life stages. Even though grazing seemed to be an important factor for the death of individuals, most individuals went missing and the reasons of their disappearance are unknown. A more frequent observation of eggs and larvae could allow to determine the reasons of death for more individuals. This would also allow to get a better understanding of the survival rate of $C$. myrmidone that could only be estimated in this study. To get a holistic understanding of survival and mortality of C. myrmidone, its whole life cycle should be considered. Knowledge stays limited because larvae in the third instar still have to hibernate, successfully pupate and develop to adults to close the life cycle. Further research on parasitoids is needed, because those were responsible for the direct loss of as many individuals as grazing animals.

\section{Conclusions}

The findings of this study provide a better understanding of the environmental conditions needed by $C$. myrmidone as eggs and larvae. The results can help informing future management at the Natura 2000 site and beyond. However, further research on the egg and larval stage of $C$. myrmidone is needed to confirm and supplement these and previous findings. The findings of this study support that a extensive management at protected sites of $C$. myrmidone is needed which requires appropriate incentives for farmers to keep their small-scale and low-intensity farming practices. $C$. myrmidone is a valuable indicator for ecological as well as socio-economic parameters. C. myrmidone is not only regarded as a flagship in European biodiversity conservation, but its conservation and the restoration of suitable habitats at the landscape scale might support the viability of many other endangered species in Europe as well. Its sensitivity to land use changes shows the importance to maintain diverse and structurally rich landscapes for the conservation of biodiversity in Europe. This underpins the need to protect European cultural landscapes and support low-intensity farming practices to provide habitats for a diversity of species that support rich and stable ecosystems and thus human well-being. To reach that goal, the currently developing management plans of the Natura 2000 site should be adapted to the needs of species, without compromising the needs of farmers and people living in and from those landscapes.

Supplementary Information The online version contains supplementary material available at https://doi.org/10.1007/s10841-021-00332-9.

Acknowledgements The study was part of a project which was funded by the German Federal Environment Ministry's Advisory Assistance Programme (AAP), supervised by the German Federal Agency for Nature Conservation (BfN) and the German Environment Agency (UBA). JL thankfully acknowledges financial support through a Junior Professorship for Research into the Sustainable Use of Natural Resources by the Robert-Bosch Foundation. For help in the field, we thank Amy Newsom, Juliane Gallersdörfer, Agnes Kastal, Andreia Sidor, Timo Jaworek and James Silvey. We are grateful for 
organizational support by Peter Lengyel. Many thanks to all farmers who accepted us on their land and to the local authorities for collaboration. We appreciate the constructive feedback provided by two anonymous reviewers.

Funding Open Access funding enabled and organized by Projekt DEAL. The study was part of a project which was funded by the German Federal Environment Ministry's Advisory Assistance Programme (AAP), supervised by the German Federal Agency for Nature Conservation (BfN) and the German Environment Agency (UBA). JL thankfully acknowledges financial support through a Junior Professorship for Research into the Sustainable Use of Natural Resources by the Robert-Bosch Foundation. The responsibility for the content of this publication lies with the authors.

Data availability Data and code available upon request to the corresponding author.

\section{Declarations}

Conflict of interest The authors declare no conflict of interest.

Ethical approval The permit Nr. 4333 has been provided by the Agentia Națională pentru Arii Naturale Protejate, Ministerul Mediului of Romania for research within the project "Conservation of the endangered butterfly Colias myrmidone in Natura 2000 sites of Romania".

Open Access This article is licensed under a Creative Commons Attribution 4.0 International License, which permits use, sharing, adaptation, distribution and reproduction in any medium or format, as long as you give appropriate credit to the original author(s) and the source, provide a link to the Creative Commons licence, and indicate if changes were made. The images or other third party material in this article are included in the article's Creative Commons licence, unless indicated otherwise in a credit line to the material. If material is not included in the article's Creative Commons licence and your intended use is not permitted by statutory regulation or exceeds the permitted use, you will need to obtain permission directly from the copyright holder. To view a copy of this licence, visit http://creativecommons.org/licenses/by/4.0/.

\section{References}

Biesmeijer JC, Roberts SP, Reemer M, Ohlemüller R, Edwards M, Peeters T, Schaffers AP, Potts SG, Kleukers RJ, Thomas CD, Settele J (2006) Parallel declines in pollinators and insectpollinated plants in Britain and the Netherlands. Science 313(5785):351-354

Blanca MJ, Alarcón R, Arnau J, Bono R, Bendayan R (2017) Nonnormal data: is ANOVA still a valid option? Psicothema 29(4):552-557

Cardinale BJ, Duffy JE, Gonzalez A, Hooper DU, Perrings C, Venail P, Narwani A, Mace GM, Tilman D, Wardle DA, Kinzig AP (2012) Biodiversity loss and its impact on humanity. Nature 486(7401):59-67

Čelik T, Bräu M, Bonelli S, Cerrato C, Vreš B, Balletto E, Stettmer C, Dolek M (2015) Winter-green host-plants, litter quantity and vegetation structure are key determinants of habitat quality for Coenonympha oedippus in Europe. J Insect Conserv 19:359-375

Crossley MS, Meier AR, Baldwin EM, Berry LL, Crenshaw LC, Hartman GL, Lagos-Kutz D, Nichols DH, Patel K, Varriano S,
Snyder WE (2020) No net insect abundance and diversity declines across US Long Term Ecological Research sites. Nat Ecol Evol 4(10):1368-1376

Curtis RJ, Brereton TM, Dennis RL, Carbone C, Isaac NJ (2015) Butterfly abundance is determined by food availability and is mediated by species traits. J Appl Ecol 52(6):1676-1684

Dennis RL (2009) Ecology of butterflies in Europe-where are we now and where to go? In: Settele J, Shreeve T, Konvička M, van Dyck $\mathrm{H}$ (eds) Ecology of butterflies in Europe. Cambridge University Press, Cambridge, pp 1-5

Dolek M, Freese A, Geyer A, Stetter H (2005) The decline of Colias myrmidone at the western edge of its range and notes on its habitat requirements. Versita Solipska 14A-1, 02-482 Warsaw, Poland 60(5):607-610

Dolek M, Freese-Hager A, Georgi M, Bräu M, Poschlod P, Stettmer C (2019) Der Hochmoorgelbling (Colias palaeno) - das Mikroklima der Larvallebensräume ist entscheidend für sein Überleben. Anliegen Natur 41(1):1-12

EEA and ETC/BD (2018) Article 17 web tool on biogeographical assessments of conservation status of species and habitats under Article 17 of the Habitats Directive. Available at\&nbsp;https:// nature-art17.eionet.europa.eu/article17/species/progress/? period $=5 \&$ group $=$ Arthropods $\&$ conclusion $=$ overall + asses sment

Erhardt A, Mevi-Schütz J (2009) Adult food resources in butterflies. In: Settele J, Shreeve T, Konvička M, van Dyck H (eds) Ecology of butterflies in Europe. Cambridge University Press, Cambridge, pp 9-16

Ewing SR, Menéndez R, Schofield L, Bradbury RB (2020) Vegetation composition and structure are important predictors of oviposition site selection in an alpine butterfly, the Mountain Ringlet Erebia epiphron. J Insect Conserv 17:1-3

Fernandez GC (1992) Residual analysis and data transformations: important tools in statistical analysis. HortScience 27(4):297-300

Freese A, Dolek M, Geyer A, Stetter H (2005) Biology, distribution, and extinction of Colias myrmidone (Lepidoptera, Pieridae) in Bavaria and its situation in other European countries. J Res Lepid 38:51-58

Freese A, Benes J, Bolz R, Cizek O, Dolek M, Geyer A, Gros P, Konvicka M, Liegl A, Stettmer C (2006) Habitat use of the endangered butterfly Euphydryas maturna and forestry in Central Europe. Anim Conserv 9(4):388-397

Gallersdörfer J, Newsom A (2019) Bericht zur Kontrolle von Larven und Eiern der Colias myrmidone in Agârbiciu. (Unpublished report)

García-Barros E, Fartmann T (2009) Butterfly oviposition: sites, behaviours and modes. In: Settele J, Shreeve T, Konvička M, van Dyck $\mathrm{H}$ (eds) Ecology of butterflies in Europe. Cambridge University Press, Cambridge, pp 29-42

Hallmann CA, Sorg M, Jongejans E, Siepel H, Hofland N, Schwan H, Stenmans W, Müller A, Sumser H, Hörren T, Goulson D (2017) More than $75 \%$ decline over 27 years in total flying insect biomass in protected areas. PloS one 12(10):e0185809

Hayes JL (1981) The population ecology of a natural population of the Pierid butterfly Colias alexandra. Oecologia 49:188-200

Horcea-Milcu AI, Abson DJ, Dorresteijn I, Loos J, Hanspach J, Fischer J (2018) The role of co-evolutionary development and value change debt in navigating transitioning cultural landscapes: the case of Southern Transylvania. J Environ Planning Manag 61(5-6):800-817

Iorgu et al (2015) Monitorizarea stării de conservare a speciilor și habitatelor din România în baza articolului 17 din Directiva Habitate. ISBN 978-606-92462-3-8

Konvicka M, Benes J, Cizek O, Kopecek F, Konvicka O, Vitaz L (2008) How too much care kills species: Grassland reserves, agri-environmental schemes and extinction of Colias myrmidone 
(Lepidoptera: Pieridae) from its former stronghold. J Insect Conserv 12(5):519-525

Loos J, Vizauer TC, Kastal A, Davies M, Hedrich H, Dolek M (2020) A highly endangered species on the edge: distribution, habitat use and outlook for Colias myrmidone in newly established Natura 2000 areas in Romania. Environ Dev Sustain 22(3):2399-2414

Marhoul P, Dolek M (2012) Action plan for the conservation of the Danube Clouded Yellow Colias myrmidone in the European Union. European Commission

Mikulcak F, Newig J, Milcu AI, Hartel T, Fischer J (2013) Integrating rural development and biodiversity conservation in Central Romania. Environ Conserv 40(2):129-137

M'Rabet C, Laglaoui A, Arakrak A, Bakkali M (2017) Aerial biomass of the laburnum (Cytisus triflorus LHérit.) in the rangelands of the Moroccan Rif. Maroccan J Biol 14:15-26

Munguira ML, García-Barros E, Cano JM (2009) Butterfly herbivory and larval ecology. In: Settele J, Shreeve T, Konvička M, van Dyck H (eds) Ecology of butterflies in Europe. Cambridge University Press, Cambridge, pp 43-54

Münsch T, Helbing F, Fartmann T (2018) Habitat quality determines patch occupancy of two specialist Lepidoptera species in wellconnected grasslands. J Insect Conserv 23(2):247-258

Roman A, Ursu TM, Onțel I, Marușca T, Pop OG, Milanovici S, SinSchneider A, Gheorghe CA, Avram S, Fărcaș S, Frink JP (2019) Deviation from grazing optimum in the grassland habitats of Romania within and outside the natura 2000 network. Habitats of the World, IntechOpen

Rosenthal G, Schrautzer J, Eichberg C (2012) Low-intensity grazing with domestic herbivores: a tool for maintaining and restoring plant diversity in temperate Europe. Tuexenia 32:167-205

Sajwaj T, Tucker G, Harley M, de Soye Y (2011) Impacts of climate change and selected renewable energy infrastructures on EU biodiversity and the Natura 2000 network. Task 2a-an assessment framework for climate change vulnerability: methodology and results. European Commission and International Union for Conservation of Nature, Brussels

Sala OE, Chapin FS, Armesto JJ, Berlow E, Bloomfield J, Dirzo R, Huber-Sanwald E, Huenneke LF, Jackson RB, Kinzig A, Leemans R (2000) Global biodiversity scenarios for the year 2100. Science 287(5459):1770-1774

Seibold S, Gossner MM, Simons NK, Blüthgen N, Müller J, Ambarlı D, Ammer C, Bauhus J, Fischer M, Habel JC, Linsenmair KE (2019) Arthropod decline in grasslands and forests is associated with landscape-level drivers. Nature 574(7780):671-674

Settele J, Kudrna O, Harpke A, Kühn I, van Swaay C, Verovnik R, Warren M, Wiemers M, Hanspach J, Hickler T, Kühn E, van Halder I, Veling K, Vliegenthart A, Wynhoff I, Schweiger O (2008) Climatic risk atlas of European butterflies. Pensoft, Sofia-Moscow
Settele J, Dover J, Dolek M, Konvička M (2009a) Butterflies of European ecosystems: impact of land use and options for conservation management. In: Settele J, Shreeve T, Konvička M, van Dyck $\mathrm{H}$ (eds) Ecology of butterflies in Europe. Cambridge University Press, Cambridge, pp 353-370

Settele J, Shreeve T, Konvička M, van Dyck H (eds) (2009b) Ecology of butterflies in Europe. Cambridge University Press, Cambridge

Sielezniew M, Deoniziak K, Dziekańska I, Nowicki P (2019) Dispersal in a metapopulation of the critically endangered Danube Clouded Yellow butterfly Colias myrmidone: implications for conservation. J Insect Conserv 23(2):291-300

Steffen W, Richardson K, Rockström J, Cornell SE, Fetzer I, Bennett EM, Biggs R, Carpenter SR, De Vries W, De Wit CA, Folke C (2015) Planetary boundaries: Guiding human development on a changing planet. Science 347(6223): 1259855

Stuhldreher G, Fartmann T (2014) When habitat management can be a bad thing: effects of habitat quality, isolation and climate on a declining grassland butterfly. J Insect Conserv 18(5):965-979

Szentirmai I, Mesterházy A, Varga I, Schubert Z, Sándor LC, Ábrahám L, Kőrösi Á (2014) Habitat use and population biology of the Danube Clouded Yellow butterfly Colias myrmidone (Lepidoptera: Pieridae) in Romania. J Insect Conserv 18(3):417-425

Thomas J (2005) Monitoring change in the abundance and distribution of insects using butterflies and other indicator groups. Philos Trans Royal Soc B Biol Sci 360(1454):339-357

Thomas JA, Telfer MG, Roy DB, Preston CD, Greenwood JJ, Asher J, Fox R, Clarke RT, Lawton JH (2004) Comparative losses of British butterflies, birds, and plants and the global extinction crisis. Science 303(5665): 1879-1881

Van Klink R, Bowler DE, Gongalsky KB, Swengel AB, Gentile A, Chase JM (2020) Meta-analysis reveals declines in terrestrial but increases in freshwater insect abundances. Science 368(6489):417-420

Vilbas M, Esperk T, Edovald T, Kaasik A, Teder T (2016) Oviposition site selection of the Alcon blue butterfly at the northern range margin. J Insect Conserv 20(6):1059-1067

Vizauer TC, Kastal Á, Loos J, Dolek M, Rákosy L (2018) About the critically endangered butterfly Colias myrmidone and one of its last refuges in the European Union in Transylvania (Romania), 10. International Zoological Congress of Grigore Antipa Museum, th

Publisher's Note Springer Nature remains neutral with regard to jurisdictional claims in published maps and institutional affiliations. 